\section{J D E}

Journal of Developing Economies
JDE (Journal of Developing Economies)

https://e-journal.unair.ac.id/JDE/index

\title{
THE INFLUENCE OF REMITTANCES ON MUTUAL TRANSACTIONS IN AN ISOLATED VILLAGE \\ Soulixay Hongsakhone*
}

*Graduate School for International Development and Cooperation (IDEC), Hiroshima University, Japan

\begin{abstract} ducted in northern Lao PDR. By using propensity score matching method, the paper estimates the average treatment effect on the treated, and it transactions mainly through increasing in rice, non-timber forest products, E-mail: paper also finds that remittances had a more significant contribution to increased stock of goods rather than consumption in households with remittances. Suggesting that households with remittances, which are both consumers and traders, tend to accumulate their resources for future transactions, this is due to external market distance, food insecurity and network constraints.
\end{abstract}

In this paper, we investigate the influence of domestic remittances on mu- Received: January, $14^{\text {th }}, 2019$ tual transactions through the trade of major products among households in Revised: May, $7^{\text {th }}, 2019$ an isolated village in a developing country. We use trade data of individual Accepted: May 23 ${ }^{\text {rd }}, 2019$ household obtaining from our own Household Survey 2015 and 2016 con- Online: June 10 2019 finds that remittances have an increasingly significant impact on mutual Soulixay Hongsakhone and livestock trading among households with remittances. Moreover, this hongsakhoneidec@gmail.com

Keywords: Remittance, Developing Country, External Market Distance, Food Insecurity, Network Constraint

JEL Classification: F17, F24, E23

To cite this document: Hongsakhone, Soulixay. (2019). The Influence Of Remittances on Mutual Transactions in An Isolated Village. JDE (Journal of Developing Economies), 4 (1), 25-42

\section{Introduction}

Domestic remittances, money sent to family members, relatives or friends within developing countries, are an important source of income and an essential component of the economy. In theory, remittances can solve expenditures of households in various ways, depending on how these money transfers are used and considered by their family members. In the developing world, remittances make a direct contribution to increasing income of the families left behind, and as such they contribute to easing budget constraints of the poorest, reducing poverty and improving average livingconditions (Acosta et al., 2008). A more optimistic view argues that remittances are a transitory source of income for families left behind, and are therefore invested, at the margin, rather than consumed. In that case, remittances mayfoster investment in human and physical capital at home (Adams \& Cuecuecha, 2010).

In this paper, we investigate the impact of remittances on mutual transactions through the tradeof locally-produced products in a disadvantaged village of a developing country. We use trade data of individual household obtaining from our own household survey data conducted in a village called Phonxay village of Ngoi district, Luang Prabang province, Lao PDR in 2015 and 2016, and we apply a propensity score matching method to estimate the average treatment effects on the treated (ATET). We find that remittances have a statistically positive impact on mutual transactions of local goods among households with remittances (WRs). This

JDE (Journal of Developing Economies) p-ISSN: 2541-1012; e-ISSN: 2528-2018

DOI: http://dx.doi.org/10.20473/jde.v4i1.11264

Open access under a Creative Commons Attribution 4.0 International

(CC-BY) 
impact also enhances local resources accumulationand consumption, suggesting that remittances directly contribute to increased investment andconsumption of intermediate inputs and final products in the corresponding village.

Our main purpose is to examine how domestic remittances as well as financial support from outside the village are used and spent for trade transactions, investment and consumption in a migrant-sending community. To understand how important remittances are, it is essential to understand their effects at national, community, and household level. However, our focus in this paper is on the impact of remittances on the reciprocity of households through their trade transactions of locally products because most households in this village are not only producers, but also consumers of these locally products, and they prefer trading each other for their production and livelihood. Through a better understanding of the impact that remittances have on development at the household level, it is interesting to explore ways to maximize this impact not only at communitylevel, but also at individual household and between household in the community. In general, severaldeveloping countries have seen remittances as an engine for local socio-economic development; because remittances can be allocated to purchase basic goods like food, healthcare expenses, and invest in human, social and physical and financial assets such as education, marriage, livestock, housing, equipment, farming activities. Therefore, investigating the influence of remittances on mutual transactions is our main research interest discussing in this paper.

Most empirical studies have pointed to the impact of remittances on household expenditure behavior and consumption in migrant-sending regions, these studies provide mixed evidence. Somefind positive impact of remittances on investment goods including education, housing and health, income generating and farming activities and some find negative impact of remittances on poverty, inequality, food consumption and education. Acosta et al. (2008)little is still known about their impact on poverty and inequality. Using a large cross-country panel dataset, we find that remittances in Latin American and Caribbean (LAC reveal that remittances sent bymigrants directly support an increasing income of households in rural areas, and these private transfers contribute to easing budget constraints of the poorest, reducing poverty and improving average living conditions in developing countries. Piras et al. (2018) use the household budget survey for 2007-2013, and 2015 survey of a sample of 126 households to assess the impact of remittances on agricultural production practices and investment. They find that recipient householdsreduce their drudgery by substituting family labor and self-produced seeds and feed with mechanization services and purchased inputs, without increasing production efficiency. They also find that the relationship between remittances and agricultural investments is very weak or negative. Because most recipients do not invest in agriculture, minority that does invest has access to remittances.

Bui etal. (2015) find that oversea remittances are associated with increasedinvestment in education and has a future social return, especially those residing in urban areas, are more likely to channel funding towards productive business investment and capital gains in comparison those without remittances. Adams \& Cuecuecha (2013) show that householdsreceiving remittances spend more at the margin on three investment goods: education, housing and health. Similar findings have been reached on Guatemala (Adams \& Cuecuecha, 2010), Mexico (Taylor \& Mora, 2006; Amuedo-Dorantes \& Pozo, 2011). Démurger \& Wang (2016) use data from the rural-urban migration in China survey, assess the impact of remittances sent to rural households on consumption-type and investment-type expenditures and they find that remittances supplement income in rural China and lead to increased consumption rather than investment. Combes \& Ebeke (2011) also find that remittances had a more significant contribution to household investment than consumption in Romania. Most remittance-use studies conclude that a large part of remittances is consumed instead of invested and thus is not put to productive use in migrant-sending areas (Taylor \& Mora, 2006).

Vacaflores (2018) indicates that increases in remittances have a negative and statistically significant impact on overall poverty and inequality in Latin America. Remittances seem to 
have a stronger effect in countries receiving small amounts and in countries with a larger share of its population working abroad. Démurger \& Wang (2016), Nguyen et al. (2017) find the evidence of a strong negative impact of remittances on education expenditure, which could be detrimental to sustaining investment in human capital in poor rural areas in China. Similarly, Acosta et al. (2008) little is still known about their impact on poverty and inequality. Using a large cross-country panel dataset, we find that remittances in Latin American and Caribbean (LAC show that remittances have increased growth, and reduced inequality and poverty in Latin America. Jimenez-Soto \& Brown (2012) find that remittances reduce the incidence of poverty by 31 percent and depth of poverty by 49 percent. The results are robust both to alternative specifications of the PSM model and to use of an alternative counterfactual income estimation method.

Aggarwal etal. (2011) show a positive, significant, and robust link between remittances and financial development in developing countries. Moreover, Coulibaly., D. (2015) finds that remittances positively influence financial development in only 4 countries (Niger, Senegal, Sierra Leone and Sudan). Ambrosius \& Cuecuecha (2016) find positive and statistically significant effects of remittances on the ownership of saving accounts, the existence of debts, and on recent borrowing. Meyer \& Shera (2017) suggest that remittances have a positive impact on growthand that this impact increases at higher levels ofremittances relative to GDP. In contrast, Combes \& Ebeke (2011) find that remittances significantly reduce household consumption instability. López-Feldman \& Chávez (2017) find that remittances decrease the likelihood that a household will participate in natural resource extraction, households that receive remittances and extract natural resources have lower environmental income and lower environmental reliance that households not receiving remittances. Furthermore, Clément (2011) uses the 2003 Tajikistan LivingStandards Measurement Survey data to assess the impact of remittances on household expenditure patterns in Tajikistan. He finds no evidence of any positive impact of remittances on investment expenditures.

However, there is no such clear evidence on how remittances are used and spent for transactionsvia trade of goods in migrant-sending communities. The impact of remittances on mutual transactions among households at the village level in developing countries is not empirically examined and found yet. Therefore, we need to understand how migration and remittances are playing a major role in mutual transactions in the villages of developing countries, especially, the impact of remittances on rural villages in Lao PDR, which is one of the least developed countries, but it is one of the fastest economic growth in Asia-Pacific region in last decade. The economy of the Lao PDR continues to grow at average 7 percent annually. Migration and remittances are one of the driven of socio- economic development in Lao PDR over the last decade. People have been moving away from a subsistence lifestyle in rural areas and migrating to towns and urban cities. Although there is no official survey and exactly data on migration and how are much internal remittances are flowing andspent on local economic transactions in rural Lao PDR. It is essential to maximize the impact that remittances have on rural household transaction capacity, income and expenditures. Our own Household Survey 2015 and 2016 conducted in a village called "Phonxay village" in northern LuangPrabang province, Lao PDR could provide us with rich data on major goods transactions and components among households who are not only trading these goods very frequently with other households, but also receiving remittances from their relatives or friends outside the village.Therefore, our research attempts to investigate how much do remittances have impact on economic transactions at household level by estimating the average treatment effects of remittances on mutualtransactions, consumption and investment in this isolated village. Moreover, its impact on mutual transactions of intermediate inputs and intermediate demand as final products among households would be examined by using propensity score matching (PSM) method.

The rest of the paper is structured as follows. In Section 2 we describe the data from our own household survey and provide descriptive analysis. The previous empirical studies and strategy adopted in our cross-sectional analysis are presented in Section 3. Estimation results is in Section 4.Section 5 concludes the results and policy implication. 
Data

To understand circular flows of goods and services between households, we conducted the household survey 2015 and 2016 and gather detailed information on household transaction and its composition within the village. The household surveys comprise all 124 households in the village, 55 out of total households does receive remittances, and 69 out of total households does not receive remittances. In this household survey, we make a transaction matrix table of $123 \times 124$ size $^{1}$, transacting from sellers to buyers, as a result, we obtain 15,252 pairs in total.

Our Household Surveys were carried out in 2015 and 2016 with the cooperation between our team from Hiroshima University and local government officials from the Trade Office of Ngoi district of Luang Prabang province, Lao PDR. In our dataset, we treated both potential outcome andcovariates variables as the OD data, flowing from suppliers or sellers to buyers in any product transactions such sales and purchases of major goods among households within the village. The data on transactions among households with remittances are treated as 6765 pairs $(55 \times 123=6765)$, whereas the data on transactions among households without remittances are treated as 8487 pairs $(69 \times 123=8487)$. This data excludes transactions, sales to, and purchases from outside the village, respectively. As we are interested in the transaction among households and other expenditures between households with remittances, we define that households with members working outside thevillage and reporting migration income are identified as households with remittances (WRs). In contrast, households with members not working and working outside the village, but do not report migration income are considered as households without remittances (WORs) in this study.

In our analysis, remittances are classified in 3 categories: remittances for transactions, consumption, and investment expenditures. Transactions include all amounts of sales and purchasesof intermediate inputs and intermediate demand (e.g. rice, NTFPs, livestock, poultry, and crops) among household (seller) $\boldsymbol{i}$ with remittances and household (buyer) $\boldsymbol{j}$ with remittances in the village, respectively. Consumption expenditures are categorized into 3 components: 1) consumer goods and services (e.g. rice, NTFPs, livestock, poultry, and crops); 2) education; and 3) healthcare services by individual household expenditure. Furthermore, investment expenditures include household spending on accumulated stock of intermediate inputs and intermediate demand (final products), such as rice, NTFPs, livestock, poultry, crops, including agricultural inputs: fertilizer, equipment, tools, and motor vehicles.

Table 1: Summary Statistics by Remittance Status-household Characteristics, 2016.

\begin{tabular}{|c|c|c|c|c|c|}
\hline & WRs (1) & WORs (0) & WRs \&WORs & $\begin{array}{c}\text { Difference in } \\
\text { means }\end{array}$ & T-test \\
\hline Age $_{i}(28<$ age< 81$)$ & $\begin{array}{c}48.20 \\
(12.35) \\
\end{array}$ & $\begin{array}{c}49.57 \\
(12.44) \\
\end{array}$ & $\begin{array}{c}48.96 \\
(12.37) \\
\end{array}$ & 1.379 & 0.615 \\
\hline Gender $_{i}($ female $=1$,other $=0$ ) & $\begin{array}{c}0.10 \\
(0.31)\end{array}$ & $\begin{array}{c}0.15 \\
(0.36) \\
\end{array}$ & $\begin{array}{c}0.13 \\
(0.34) \\
\end{array}$ & 0.050 & 0.805 \\
\hline Education $_{\mathrm{i}}(0<\text { year }<12)^{2}$ & $\begin{array}{c}6.12 \\
(2.68)\end{array}$ & $\begin{array}{c}5.49 \\
(2.89) \\
\end{array}$ & $\begin{array}{c}5.77 \\
(2.80) \\
\end{array}$ & -0.634 & 1.253 \\
\hline $\begin{array}{l}\text { Household size } \\
(4<\text { member<12) }\end{array}$ & $\begin{array}{c}5.70 \\
(1.69)\end{array}$ & $\begin{array}{c}5.88 \\
(1.52)\end{array}$ & $\begin{array}{c}5.80 \\
(1.60)\end{array}$ & 0.174 & 0.602 \\
\hline Land size $_{i}(0<$ area $(\mathrm{Ha})<5)$ & $\begin{array}{l}1.26 \\
(0.70)\end{array}$ & $\begin{array}{l}1.25 \\
(0.66)\end{array}$ & $\begin{array}{c}1.26 \\
(0.68)\end{array}$ & -0.012 & -0.101 \\
\hline Observations (N) & 55 & 69 & 124 & & \\
\hline
\end{tabular}

${ }^{1}$ This information on transactions among households used in this paper was extracted from the village input-output tables (VIOT), and this VIOT was prepared and made by Hongsakhone \& Ichihashi (2018). 
Notes: WRs and WORs mean households with remittances, and households without remittances, respectively.The last two columns show the differences in means of all observed characteristics of households, and t-test.Age is age of the head of householdi; Sex is 1 if household head is a female and 0 if a male, Education is a number of schooling year of the head of householdi: if no formal education is 0 , completed primary school is 5 , completed secondary school is 8 and completed higher education is 12; Household size is number of familymembers in householdi; Land size is agricultural land areas owned by householdi (ha). Standard deviations inparentheses. Difference is a mean difference in all observed characteristics of WORs and WRs.d

Source: Household Survey Data conducted by Authors, March 8-29, 2016.

To explore the mutual transactions of locally-products among households in this village, we consider the major economic activities by ranking the products that are frequently transacted and traded in the village. From our dataset, rice is the main transaction, followed by NTFPs, livestock, poultry and crops. Rice transactions are mainly referred to upland rice production; livestock transactions include native cattle, buffalo, goat, and pig; poultry transactions are chicken and duck; crops transactions are vegetables, maize/corn, pumpkin, and ginger; and non-timber forest products (NTFPs) transactions are bamboo shoots, rattan shoots, PuekMeuk, and herbal roots, respectively.

Table 1 and Table 2 show the characteristics of households with remittances (WRs) and households without remittances (WORs) in terms of age of household head, sex, education, household size and land size. We find that WRs and WORs strongly differ in terms of many observable and unobservable characteristics. These characteristics might be correlated with the outcome variables. Households that receive remittances tend to be larger in term of education level of household head, and land size, while households that does not receive remittances tend to be largerin terms of age of household head, gender and household size, respectively. Table 3 provides a comparison of the two groups in terms of trade transactions of intermediate inputs and intermediatedemand as final products in the village, surprisingly, there are significant differences in transactionsof locally-produced products have been used as intermediate inputs and final products between twogroups in the village.

Table 2: Summary Statistics by Remittance Status - Characteristics of a Pair of Household Tades Each Other, 2016

\begin{tabular}{|c|c|c|c|c|c|}
\hline & WRs (1) & WORs (0) & WRs \&WORs & $\begin{array}{c}\text { Difference in } \\
\text { means }\end{array}$ & T-test \\
\hline $\operatorname{Age}_{\mathrm{ij}}(28<$ age $<81)$ & $\begin{array}{c}48.20 \\
(12.23) \\
\end{array}$ & $\begin{array}{r}49.57 \\
(12.35) \\
\end{array}$ & $\begin{array}{c}48.96 \\
(12.32) \\
\end{array}$ & $1.379 * * *$ & 6.878 \\
\hline $\begin{array}{l}\text { Gender }_{\mathrm{ij}} \text { (female }=1 \text {, other } \\
=0 \text { ) }\end{array}$ & $\begin{array}{c}0.10 \\
(0.31)\end{array}$ & $\begin{array}{c}0.15 \\
(0.36)\end{array}$ & $\begin{array}{c}0.13 \\
(0.34)\end{array}$ & $0.050 * * *$ & 9.001 \\
\hline Education $_{\mathrm{ij}}(0<\text { year }<12)^{2}$ & $\begin{array}{c}6.12 \\
(2.65) \\
\end{array}$ & $\begin{array}{c}5.49 \\
(2.89) \\
\end{array}$ & $\begin{array}{c}5.77 \\
(2.79) \\
\end{array}$ & $-0.634 * * *$ & 14.010 \\
\hline $\begin{array}{l}\text { Household size }_{i j} \\
(4<\text { member }<12)\end{array}$ & $\begin{array}{c}5.70 \\
(1.68)\end{array}$ & $\begin{array}{c}5.88 \\
(1.51)\end{array}$ & $\begin{array}{c}5.80 \\
(1.59)\end{array}$ & $0.174^{* * *}$ & 6.741 \\
\hline Land size $_{\mathrm{ij}}(0<$ area $(\mathrm{Ha})<5)$ & $\begin{array}{c}1.26 \\
(0.70)\end{array}$ & $\begin{array}{c}1.25 \\
(0.66)\end{array}$ & $\begin{array}{c}1.26 \\
(0.67)\end{array}$ & -0.012 & -1.134 \\
\hline Observations (N) & 6765 & 8487 & 15252 & & \\
\hline
\end{tabular}

Notes: WRs and WORs mean households with remittances, and households without remittances, respectively.The last two columns show the differences in means of all observed characteristics of households, and t-test.Age is age of the head of householdi and householdj; Sex is 1 if the head of householdi and householdj is a female and 0 if a male, Education is a number of schooling year of the head of householdi and householdj: if no formal education is 0 , completed primary school is 5 , completed secondary school is 8 and completed higher education is 12; Household size is number of family members in householdi and household; Land sizeis agricultural land areas owned by householdi and householdj (ha). Standard deviations in parentheses. Difference is a mean difference in all observed characteristics of WORs and WRs.

Source: Household Survey Data conducted by Authors, March 8-29, 2016. 
The computation of amount of trade transactions among WORs or among WRs show interesting features because the transactions among households who are receiving remittances tend to be larger in terms of rice transaction, NTFPs, and livestock transaction, respectively. This indicates that WRs can make purchase or sale transactions of intermediate inputs as well as final products better than WORs. In addition, there are also strong significant differences in consumption expenditures between WORs and WRs. This means that WRs have a higher spending capacity ratherthan WORs in rural Lao PDR. Moreover, these WORs have a lower income earnings capacity and per capita consumption level than WRs in this village. Furthermore, accumulated (stock) products orcash savings of WORs are relatively low compared to the accumulated products of WRs. The raw statistics from our Household Survey also provide strong evidence on the use of remittances by households in the village, and we find that remittances represent a large share of income for households who are frequently doing trade of goods and services in the village. Surprisingly, most households with remittances are under non-poor group, which seem to spend a significantly higher share of their incomes on both transactions and consumption, as well as spending more on family investment in tradable and accumulated products rather than households without remittances in the village. In addition, we also find that, due to poor situation, and products shortage in some WORs, they can't afford to produce enough home products or most products produced by these WRs wentto consumption rather than investment or stock for the future use.

Table 3: Summary Statistics by Remittance Status- Mutual Transactions, Consumption, And Investment, 2016.

\begin{tabular}{|c|c|c|c|c|c|}
\hline \multicolumn{6}{|c|}{ I. Mutual Transactions } \\
\hline & WRs (1) & WORs (0) & WRs \& WORs & Difference in means & T-Test \\
\hline (1) Rice & $\begin{array}{c}68.01 \\
(246.43)\end{array}$ & $\begin{array}{c}19.93 \\
(125.30)\end{array}$ & $\begin{array}{c}41.25 \\
(190.37)\end{array}$ & $-48.079 * * *$ & 15.618 \\
\hline (2) NTFPs & $\begin{array}{c}22.47 \\
(105.11)\end{array}$ & $\begin{array}{c}1.57 \\
(13.32)\end{array}$ & $\begin{array}{c}10.84 \\
(71.46)\end{array}$ & $-20.903 * * *$ & 18.137 \\
\hline (3) Livestock & $\begin{array}{c}20.08 \\
(294.15) \\
\end{array}$ & $\begin{array}{c}7.86 \\
(104.28) \\
\end{array}$ & $\begin{array}{c}13.28 \\
(210.86)\end{array}$ & $-12.218^{* * *}$ & 3.556 \\
\hline (4) Poultry & $\begin{array}{c}5.31 \\
(31.72)\end{array}$ & $\begin{array}{c}3.38 \\
(23.72)\end{array}$ & $\begin{array}{c}4.24 \\
(27.57)\end{array}$ & $-1.928 * * *$ & 4.293 \\
\hline (5) Crops & $\begin{array}{c}3.52 \\
(25.87)\end{array}$ & $\begin{array}{c}2.49 \\
(20.62)\end{array}$ & $\begin{array}{c}2.95 \\
(23.10)\end{array}$ & $-1.027 * * *$ & 2.727 \\
\hline Observations & 6765 & 8487 & 15252 & & \\
\hline \multicolumn{6}{|l|}{ II. Consumption } \\
\hline & WRs (1) & WORs (0) & WRs \& WORs & Difference in means & T-Test \\
\hline (1) Rice & $\begin{array}{c}2742.81 \\
(1016.18)\end{array}$ & $\begin{array}{l}2425.21 \\
(771.83)\end{array}$ & $\begin{array}{l}2566.08 \\
(898.77)\end{array}$ & $-317.600 * *$ & 1.977 \\
\hline (2) NTFPs & $\begin{array}{c}77.81 \\
(88.08)\end{array}$ & $\begin{array}{l}57.76 \\
(56.74)\end{array}$ & $\begin{array}{l}66.65 \\
(72.70)\end{array}$ & $-20.057^{*}$ & 1.534 \\
\hline (3) Livestock & $\begin{array}{c}462.72 \\
(1382.77) \\
\end{array}$ & $\begin{array}{c}113.33 \\
(249.47) \\
\end{array}$ & $\begin{array}{l}268.30 \\
(950.90)\end{array}$ & $-349.393 * *$ & 2.053 \\
\hline (4) Poultry & $\begin{array}{c}287.63 \\
(281.87) \\
\end{array}$ & $\begin{array}{c}158.40 \\
(200.76)\end{array}$ & $\begin{array}{c}215.72 \\
(247.62)\end{array}$ & $-129.230 * * *$ & 2.978 \\
\hline (5) Crops & $\begin{array}{c}653.70 \\
(1055.75) \\
\end{array}$ & $\begin{array}{c}451.08 \\
(450.95) \\
\end{array}$ & $\begin{array}{c}540.95 \\
(782.29)\end{array}$ & $-202.622 *$ & 1.439 \\
\hline $\begin{array}{l}\text { (6) Education Ex- } \\
\text { pense }\end{array}$ & $\begin{array}{c}577.27 \\
(410.94)\end{array}$ & $\begin{array}{c}473.18 \\
(343.91)\end{array}$ & $\begin{array}{c}519.35 \\
(377.12)\end{array}$ & $-104.084 *$ & 1.535 \\
\hline (7) Health Expense & $\begin{array}{c}1635.45 \\
(5383.86)\end{array}$ & $\begin{array}{c}725.36 \\
(387.73)\end{array}$ & $\begin{array}{c}1129.03 \\
(3607.59)\end{array}$ & $-910.092 *$ & 1.401 \\
\hline
\end{tabular}




\begin{tabular}{|c|c|c|c|c|c|}
\hline Observations & 55 & 69 & 124 & & \\
\hline \multicolumn{6}{|c|}{ III. Investment (stock) } \\
\hline & WRs (1) & WORs (0) & WRs \& WORs & Difference in means & T-Test \\
\hline (1) Rice & $\begin{array}{c}11921.64 \\
(46713.11)\end{array}$ & $\begin{array}{l}144.56 \\
(38.86)\end{array}$ & $\begin{array}{c}5368.26 \\
(31504.18)\end{array}$ & $-11777.070 * * *$ & 2.096 \\
\hline (2) NTFPs & $\begin{array}{c}5978.45 \\
(23206.30) \\
\end{array}$ & $\begin{array}{c}141.95 \\
(194.91) \\
\end{array}$ & $\begin{array}{c}2730.72 \\
(15650.11)\end{array}$ & $-5836.498 * * *$ & 2.091 \\
\hline (3) Livestock & $\begin{array}{c}2181.81 \\
(4991.06) \\
\end{array}$ & $\begin{array}{c}894.34 \\
(1392.47) \\
\end{array}$ & $\begin{array}{c}1465.40 \\
(3524.31) \\
\end{array}$ & $-1287.470 * *$ & 2.047 \\
\hline (4) Poultry & $\begin{array}{c}438.81 \\
(458.38)\end{array}$ & $\begin{array}{c}327.97 \\
(273.10) \\
\end{array}$ & $\begin{array}{c}377.13 \\
(369.51)\end{array}$ & $-110.847^{* *}$ & 1.671 \\
\hline (5) Crops & $\begin{array}{c}30.45 \\
(20.50) \\
\end{array}$ & $\begin{array}{c}29.78 \\
(24.03) \\
\end{array}$ & $\begin{array}{c}30.08 \\
(22.45)\end{array}$ & -0.671 & 0.164 \\
\hline (6) Farm inputs & $\begin{array}{c}15004 \\
(63907) \\
\end{array}$ & $\begin{array}{c}1576.95 \\
(1059.37) \\
\end{array}$ & $\begin{array}{c}7532.5 \\
(42877.74) \\
\end{array}$ & $-13427.040 * *$ & 1.746 \\
\hline Observations & 55 & 69 & 124 & & \\
\hline
\end{tabular}

Note: Standard deviations in parentheses. The last two columns show the significance level by t-test between households without remittances (WORs) and households with remittances (WRs). ${ }^{* * *}$ significant at $1 \%$, ${ }^{* *}$ significant at $5 \%, *$ significant at $10 \%$ respectively. The amount of transactions shown here are expressed in Lao Kip (1.000 Kip).

Source: Household Survey Data conducted by Authors, March 8-29, 2016.

\section{Methodology}

Since the focus here is on remittance impact on trade transactions of intermediate inputs and intermediate demand among households in a rural village, it is important to clarify how remittance incomes are measured and defined. Exploring the impact of remittances on trade transactions of locally-produced products between rural households requires to address some potential endogeneityof the remittance characteristics. Data on remittances used in this paper includes transfers received in forms of money (cash); food; and non-food items such as household appliances (chairs, tables, TV, refrigerators) and equipment. In this study each household which report having migrants and receiving remittances from outside the village is classified as households with remittances (WRs). Households which report having no migrants or having migrants, but do not report receiving remittances are considered as households without remittances (WORs). Because our data is OD dataflowing from sellers to buyers as mentioned above, so that, a pair of households takes a value of 1 ifboth or one is seller or buyer receives remittances and trade with each other, otherwise 0 (a pair of households takes a value of 0 if both (buyer and seller) or one of them do not receive remittances, but they trade each other.

In impact assessment studies, biases always come from three sources; (i) selection bias, (ii) self-selection bias, and (iii) difference in observable characteristics. To overcome this selection bias, firstly, we can use t-statistics approach to measure the difference in socio-economic impact of remittances. In this approach, we can measure the remittance impact using all WRs \& WORs ignoring selection bias, and counterfactual. Secondly, the conceptual framework from Rosenbaum and Rubin (1983) and Heckman, et al. (1998); which has been widely used to identify the bias in the estimates.

The previous empirical literatures that estimate the impact of remittances on receiving households using cross-sectional data usually employ two main techniques to overcome this selectionproblem: an instrumental variable (IV) approach (e.g. Adams \& Cuecuecha, 2010; Adams \& Cuecuecha, 2013) or a propensity score matching (PSM) approach (e.g. Démurger \& Wang, 2016; Bertoli \& Marchetta, 2014; Jimenez-Soto \& Brown, 2012; Clément, 2011). In this paper, we employ the 
secondapproach: PSM approach (Rosenbaum \& Rubin, 1983). As discussed below, this approach is not without its own faults as it relies on a strong identifying assumption, and various sensitivity tests areneeded to assess the quality of the estimates (Caliendo \& Kopeinig, 2008).

In our estimation, we treated both potential outcome and covariates variables as the OD data, flowing from suppliers (sellers) to buyers (demanders) in product transactions. This constitutes a matrix form of $123 \times 124(15,252)$ size. We decompose total transaction into five product transaction, each transaction is defined as potential outcome that represents each composition of the total product transactions such as rice, livestock, poultry, crops, and NTFPs transactions among household $\boldsymbol{i}$ and household $\boldsymbol{j}$, respectively. In addition, we also decompose investments in total productions into fivetypes of product investment as same as product transaction plus one item as investment in agricultural inputs such as buying fertilizer, equipment, and tools. For consumption expenditures are decomposed into five product consumption, education, health, and food.

However, no empirical literatures that apply PSM approach and the OD data of individual households to estimate the impact of remittances on transactions among households in both developed and developing countries, this paper attempts to estimate average treatment effects of remittances on transactions among households using a PSM method with the OD data obtained fromhousehold survey conducted in the Phonxay village of Ngoi district of Luang Prabang province, andLao PDR in 2015 and 2016.

In this study, the remittance-response function is estimated first. The major concern in the PSMapproach is the determination of which explanatory variables should be included in the remittance- response function to estimate the probability of a household receiving remittances or not. This probability depends on characteristics of households with remittances and households without remittances. The dependent variable represents the status of households receiving remittance incomeor not. E.g. a dependent variable taking a value ' 1 ' when a household receives remittances and ' 0 ' when it does not.

$$
P(X)=\operatorname{Pr}\left(T_{i}=1 \mid X\right)
$$

$P(X)$ is a propensity of being treated or a dichotomous variable (remittances), where $P(X)=1$ if a household receives remittances, otherwise $0 . X$ is a vector of individual or household level characteristics (covariates). These characteristics may motivate the migrated worker's decision to remit income and affect remittance income but not the outcome variables.

From the above definition, average treatment effect on the treated (ATET) for the mutual transactions, and for investment and consumption in households with remittances can be estimated by equation 2 , and equation 3 , respectively.

$$
\begin{gathered}
A T E T=E\left[Y_{i j}(1) \mid T_{i}=1\right]-E\left[Y_{i j}(0) \mid T_{i}=1\right] \\
A T E T=E\left[Y_{i}(1) \mid T_{i}=1\right]-E\left[Y_{i}(0) \mid T_{i}=1\right]
\end{gathered}
$$

$Y_{i j}$ and $Y_{i}$ is the outcome variables representing the mutual transactions, consumption and investmentand their components, respectively. $T_{i}$ is a real treatment, whether households trade with each other receive or not receive remittances. $i$ represents a seller's characteristics, and $j$ represents buyer's characteristics, respectively. Estimating this ATET poses an identification problem because $\mathrm{Y}_{\mathrm{ij}}(0)$ the non-treatment outcome of the treated group, cannot be observed directly for treated households and must be estimated. Matching methods provide a solution to estimate the counterfactual outcomefor the treated households in the hypothetical absence of treatment, by pairing each treated householdwith a non-treated household that is similar in terms of its observed characteristics (Démurger \& Wang, 2016). Furthermore, (Rosenbaum \& Rubin, 1983) have shown that if assignment to treatmentis strongly ignorable given $X$, then assignment to treatment is also strongly given the propensity score $p(X)$, which means that we can reduce $X$ to one dimension and match on $p(X)$ instead.

Before we estimate the average treatment effect on the treated (ATET), we first need to 
construct a statistical comparison group based on a model of the probability of participating in the treatment, using a set of observed characteristics. Then, households that receive remittances are matched based on this probability, or propensity score, to non-receiving households. The ATET canfinally be calculated as the mean difference in outcomes across the two groups.

Our main treatment is whether a pair of household trades with each other receives remittances or a household who trades with others receives remittances in the year 2015. The main reason why we use remittance data for 2015 not 2016, because households that received remittances can't recognize when they received and spent for product transactions, as well as consumption in the same year (2016) and stock of those products. Therefore, we used the remittance data obtained from our first household survey in 2015. This data can be used to estimate the impact of remittances on the transactions, consumptions and investment in later year (2016). In the benchmark treatment, WRs are matched to WORs, this matching allows examining the impact of remittances among householdsin the village.

The first step of PSM analysis consists in estimating the propensity score with selected covariates. As recommended in the literature (Caliendo \& Kopeinig, 2008; Démurger \& Wang, 2016), only variables that influence simultaneously the treatment status (e.g. remittance-receiving households) and the outcome variables (e.g. transactions, consumption and investment) should be included in this first step because unconfoundedness requires the outcome to be independent of treatment conditional on the propensity score. Moreover, only covariates that are unaffected by the treatment, thus, preferably observed prior to the treatment should be included in the model to avoid endogeneity due to exposure to the treatment. As our database is the OD data and we have information about each household head's characteristics such as age of the head of household, yearsof education schooling, household size that includes total household member, incorporating this information into our covariate variables may reasonably help reduce the potential endogeneity issue.

This paper follows previous papers that have recently applied the PSM approach (Démurger \&Wang, 2016) to analyze of remittances impact on consumption and investment expenditures, and we also try to estimate remittance impact on mutual transactions in the village. Using OD data of the sellers and buyers extracting from our $\mathrm{VIOT}^{2}$ may produce an interesting result. Then, we incorporatevariables related to the household head and household characteristics in the covariates (e.g. the education level of household head, age of household head, household size, land size), as it is usuallydone in most literature, claiming that household headship could be endogenous to the decision of household members to migrate and remit transfers.

The validity of PSM depends on several conditions. First, matching approach assumes conditional independence, which means that conditional on observable variables $X$, the assignment to treatment is random, and the outcomes of non-treated units can be used to approximate the counterfactual outcome of treated units in the absence of treatment (Démurger \&Wang, 2016). Balancing tests allow checking whether observations with the same propensity score have the samedistribution of covariates $X$, independent of the assignment. Table 5 and 6 show the balancing tests for the main treatment, which check the equality of the means of the covariates in the model before and after matching, as well as the standardized bias before and after matching (Lee, 2013). It shows that after matching, the covariates are almost balanced between the treatment and the control groups.

Table 4 displays both probit and logit estimation used to generate the propensity score for the full samples of consumption and investment expenditures in each individual household, respectively. In this estimation, we use a set of covariates as mentioned above, and only covariates that are unaffected by the treatment (a household who does receive remittances) should be included in the model to avoid endogeneity.

\footnotetext{
${ }^{2}$ This information about transactions among households is prepared and made by Hongsakhone \& Ichihashi (2018) when making a village Input-Output Table (VIOT) to measure the interdependency among households in that village.
} 
Table 4: Probit and Logit Estimation for Propensity Score

\begin{tabular}{|c|c|c|}
\hline Covariates $(\mathrm{X})$ & Coefficients (1) & Coefficients (2) \\
\hline $\operatorname{Age}_{i}(28<$ age $<81)$ & $0.0002(0.0101)$ & $0.0003(0.016)$ \\
\hline Gender $_{i}($ Female $=1$, other $=0)$ & $-0.1856(0.3495)$ & $-0.3032(0.5678)$ \\
\hline Education $_{i}(0<\text { years }<12)^{2}$ & $0.0532(0.0462)$ & $0.0867(0.0749)$ \\
\hline Household size $_{i}(4<$ member $<12)$ & $-0.0722(0.0809)$ & $-0.1176(0.0130)$ \\
\hline${\text { Land } \text { size }_{i}(0<\text { area }(\mathrm{Ha})<5)}$ & $0.0364(0.1746)$ & $0.0597(0.2792)$ \\
\hline Constant & $-0.0647(0.6354)$ & $-0.1030(1.0193)$ \\
\hline Pseudo $\mathrm{R}^{2}$ & 0.0160 & 0.0161 \\
\hline Observations (N) & 124 & 124 \\
\hline
\end{tabular}

Note: Standard errors in parentheses. (1), and (2) mean probit and Logit estimation for propensity score, respectively.

Source: Household Survey Data conducted by Authors, March 8-29, 2016.

Table 5 also displays both probit and logit estimation used to generate the propensity score forthe full sample of mutual transactions among pair of households with remittances. In this estimation, we use a set of covariates as mentioned above, and only covariates that are unaffected by the treatment (households with remittances) should be included in the model to avoid endogeneity.

Table 5: Probit and Logit Estimation For Propensity Score

Dependent variable: Whether a pair of households trading with each other receive remittances

\begin{tabular}{lcc}
\hline \multicolumn{1}{c}{ Covariates (X) } & Coefficients (1) & Coefficients (2) \\
\hline Age $_{i j}(28<$ age<81) & $0.0002(0.0009)$ & $0.0003(0.0014)$ \\
\hline Gender $_{i j}($ Female $=1$, other $=0)$ & $-0.1856^{* * *}(0.0315)$ & $-0.3032^{* * *}(0.0512)$ \\
\hline Education $_{i j}(0<$ year $<12)$ & $0.0532^{* * *}(0.0041)$ & $0.0867^{* * *}(0.0067)$ \\
\hline Household size $_{i j}(4<$ member<12) & $-0.0722^{* * *}(0.0072)$ & $-0.1176^{* * *}(0.0117)$ \\
\hline Land size $_{i j}(0<$ area $(\mathrm{Ha})<5)$ & $0.0364^{* *}(0.0157)$ & $0.0597^{* * *}(0.0251)$ \\
\hline Constant $\left.^{2}\right)$ & $-0.0647(0.0572)$ & $-0.1030(0.0919)$ \\
\hline Pseudo $\mathrm{R}^{2}$ & 0.0160 & 0.0161 \\
\hline Observations $(\mathrm{N})$ & 15252 & 15252 \\
\hline
\end{tabular}

Note: Standard errors in parentheses. (1), and (2) mean probit and Logit estimation for propensity score, respectively.

Source: Household Survey Data conducted by Authors, March 8-29, 2016.

Second, a common support must be imposed to mitigate the bias in the estimate and this restriction requires that the overlap in propensity scores across the participant and non-participant samples is sizable. The comparison of the distributions of estimated propensity score among WORs and WRs (Fig. 1 \& 2) shows that the large overlap, which indicates that observable that predict the probability of receiving remittances are distributed very similarly across the two groups.

The second step in PSM comprises using the estimated propensity scores to match each remittance-receiving household with its "nearest" non-receiving household. Theoretically, various matching methods are available. However, in this paper, we use a Kernel estimator that matches the outcome of each treated household to a weighted average of the outcomes of all the control households, assigning greatest weight to match controls with the closet propensity score. Kernel matching method offers the lower variance because more information 
is used. Therefore, the averagetreatment effects on the treated (ATET) shown in Tables 8, 9 and 10 are derived from this procedure.Other methods of estimating treatment effects: Nearest Neighbor Matching (NN-MATCH), InverseProbability Weighting (IPW), Inverse Probability Weighting (IPWRA), and Regression Adjustment(RA) are not discussed here, but the results of these methods are reported here to check robustness results only.

Table 6: Balancing Tests For Propensity Score Matching Using OD Data On MutualTransactions

\begin{tabular}{|c|c|c|c|c|}
\hline \multicolumn{5}{|l|}{ Covariate balance summary } \\
\hline & Raw & Matched & & \\
\hline No. of observation & 15252 & 13530 & & \\
\hline Treated observation & 6765 & 6765 & & \\
\hline \multirow[t]{2}{*}{ Control observation } & 8487 & 6765 & & \\
\hline & \multicolumn{2}{|c|}{ Standardized differences } & \multicolumn{2}{|c|}{ Variance rasio } \\
\hline Covariates $(\mathrm{X})$ & Raw & Matched & Raw & Matched \\
\hline$A g e_{i j}(28<$ age $<81)$ & -0.1121 & -0.0932 & 0.9805 & 0.1299 \\
\hline Gender $_{i j}($ Female $=1$, other $=0)$ & -0.1480 & -0.1092 & 0.7252 & 1.7846 \\
\hline Education $_{i j}(0<$ year $<12)$ & 0.2293 & $-0.79 e-15$ & 0.8553 & 1.2811 \\
\hline $\begin{array}{l}\text { Household size }_{i j} \\
(4<\text { member }<12)\end{array}$ & -0.1092 & 0.0897 & 1.2251 & 0.9447 \\
\hline Land size $_{i j}(0<$ area $(\mathrm{Ha})<5)$ & 0.0184 & 0.0951 & 1.1236 & 1.3525 \\
\hline
\end{tabular}

Note: The balancing test refers to the benchmark specification of the propensity score with all householdswith remittances included in the treatment group.

Source: Authors' calculation, September 30, 2018.

Figure 1: Distribution Of Estimated Propensity Scores of Treatment And Control Groups, Before And After Matching

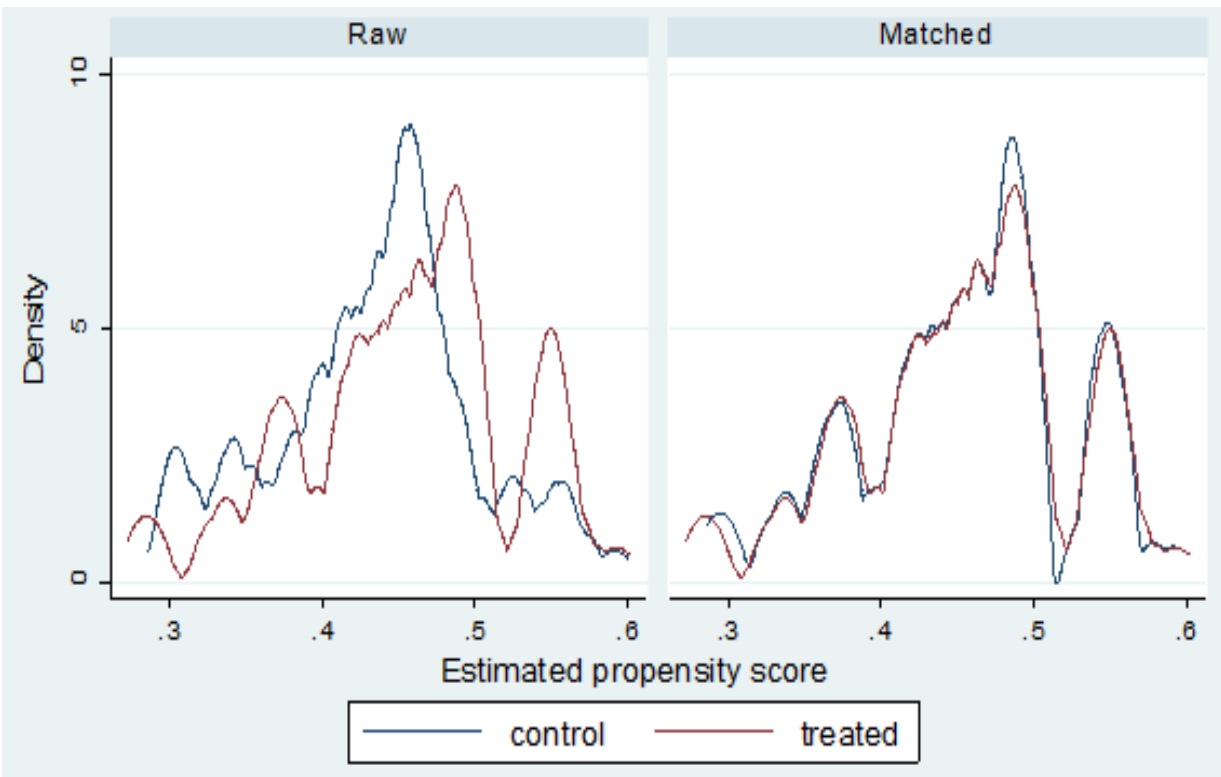

Source: Authors' calculation, September 30, 2018. 


\section{Figure 2: Distribution of Estimated Propensity Scores of Treatment and Control Groups,} Before AndAfter Matching

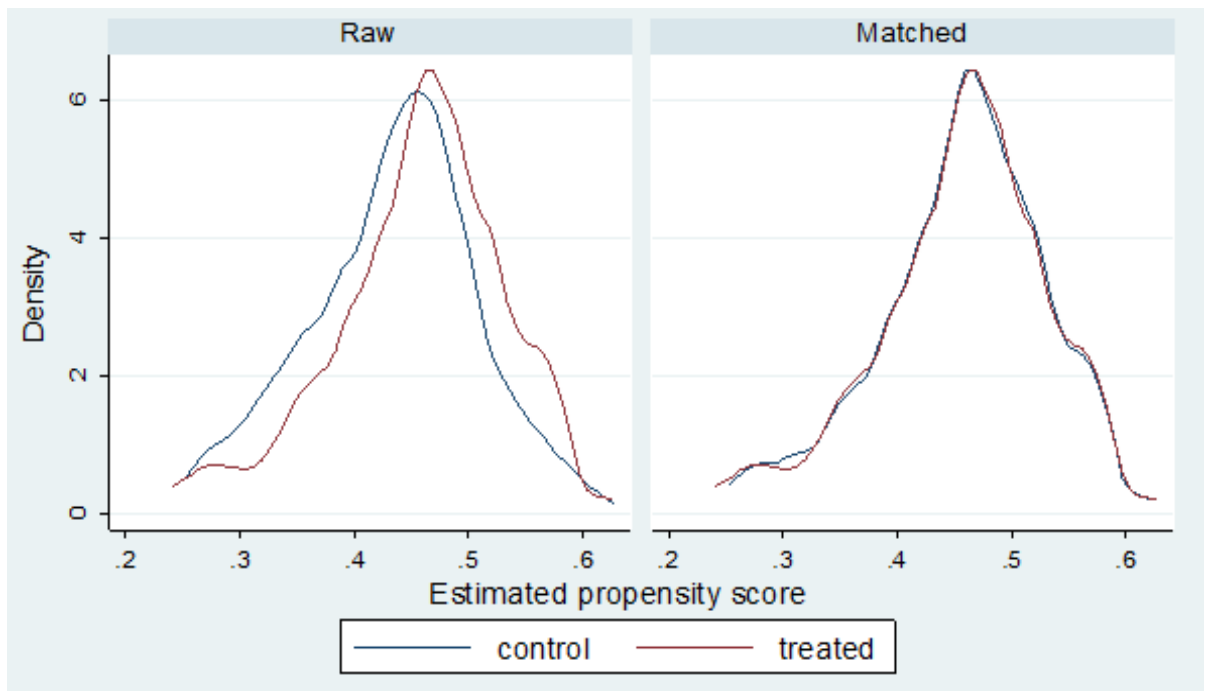

Source: Authors' calculation, September 30, 2018

Table 7: Balancing Tests For Propensity Score Matching

\begin{tabular}{|c|c|c|c|c|}
\hline \multicolumn{5}{|l|}{ Covariate balance summary } \\
\hline & Raw & Matched & & \\
\hline No. of observation & 124 & 110 & & \\
\hline Treated observation & 55 & 55 & & \\
\hline Control observation & 69 & 55 & & \\
\hline & \multicolumn{2}{|c|}{ Standardized differences } & \multicolumn{2}{|c|}{ Variance ratio } \\
\hline Covariates (X) & Raw & Matched & Raw & Matched \\
\hline Age $(28<$ age $<81)$ & -0.1112 & -0.0923 & 0.9841 & 0.9263 \\
\hline Gender (Female $=1$, other $=0$ ) & -0.1468 & -0.1082 & 0.7279 & 0.7819 \\
\hline Education $(0<$ years $<12)$ & 0.2274 & 0.0001 & 0.8585 & 1.3286 \\
\hline Household size $(4<$ members $<12)$ & -0.1083 & 0.0889 & 1.2297 & 1.1633 \\
\hline Land size $(0<\operatorname{size}(\mathrm{Ha})<5)$ & 0.0182 & 0.0943 & 1.1278 & 2.3525 \\
\hline
\end{tabular}

Note: The balancing test refers to the benchmark specification of the propensity score with all householdswith remittances included in the treatment group.

Source: Authors' calculation, September 30, 2018.

\section{Results}

\section{Impact of Remittances on Mutual Transactions}

Table 8 presents the ATET estimates of households with remittances (WRs) for the entire sample on a set of various outcomes related to mutual transactions of intermediate inputs and intermediate demand between households with remittances over the year 2016. These products are the main economic activities in this village such as rice, poultry, livestock, crops and NTFPs transactions. Concerning disaggregate transaction, our estimates indicate that rice and NTFPs transactions are significantly increasing among other transactions in WRs, which 
are not only producers but traders of these products in the village. In our estimation, the focus is mainly on PSMmethods providing a statistically significant result. Table 8 shows that remittances are playing significant roles in major product transactions, especially, their impact on rice transaction among households with remittances, followed by NTFPs, livestock, poultry, and crops transactions, indicating that a 1000 Kip (US\$1,2) increase in remittances would lead to an average of $47838 \mathrm{Kip}(\text { US } \$ 5,97)^{3}, 20860 \mathrm{Kip}$ (US\$ 2,6), and $13720 \mathrm{Kip}$ (US\$ 1,71 ) increase in rice, NTFPs, and livestocktransactions among WRs, respectively. These findings provide new evidences to the empirical literature on the impact of remittances sent by rural-to-urban migrants on the inter-household transactions. Furthermore, remittances can facilitate the trade of locally-produced products using asintermediate inputs and intermediate demand in a disadvantaged area in Lao PDR, and these remittances spent by WRs also have a favorably impact on the commerce activities in the areas wherecommunity markets are a heart of transactions, and this impact encourages some potentially positiveeffects of remittances on streaming a circular flow of locally-produced products, as well as solving the budget constraint of WRs in the corresponding village.

Table 8: ATET Estimation: Impact of Remittances on Mutual Transactions

\begin{tabular}{|c|c|c|c|c|c|c|c|c|c|c|}
\hline \multirow{2}{*}{$\begin{array}{c}\text { Remittance } \\
\text { (1 vs 0) }\end{array}$} & \multicolumn{2}{|c|}{ PSM } & \multicolumn{2}{|c|}{ NN-MATCH } & \multicolumn{2}{|c|}{ IPW } & \multicolumn{2}{|c|}{ IPWRA } & \multicolumn{2}{|c|}{ RA } \\
\hline & ATET & S.E. & ATET & S.E. & ATET & S.E. & ATET & S.E. & ATET & S.E. \\
\hline (1) Rice & $47.838 * * *$ & 4.059 & $47.292 * * *$ & 3.774 & $47.876 * * *$ & 3.322 & $47.876 * * *$ & 3.322 & $47.834 * * *$ & 3.324 \\
\hline (2) NTFPs & $20.860 * * *$ & 1.338 & $21.009 * * *$ & 1.297 & $20.875^{* * *}$ & 1.286 & $20.875^{* * *}$ & 1.286 & $20.885^{* * *}$ & 1.286 \\
\hline (3) Lives tock & $13.720 * * *$ & 3.724 & $13.110 * * *$ & 3.905 & $11.818^{* * *}$ & 3.834 & $11.818^{* * *}$ & 3.834 & $11.839 * * *$ & 3.814 \\
\hline (4) Poultry & $01.752^{* * *}$ & 0.646 & $02.150 * * *$ & 0.538 & $01.928^{* * *}$ & 0.470 & $01.928^{* * *}$ & 0.470 & $01.914^{* * *}$ & 0.471 \\
\hline (5) Crops & $01.047 * *$ & 0.567 & 00.538 & 0.547 & $00.986 * *$ & 0.389 & $00.986 * *$ & 0.389 & $00.995 * * *$ & 0.388 \\
\hline $\begin{array}{l}\text { Observatio } \\
n(N)\end{array}$ & 15,252 & & 15,252 & & 15,252 & & 15,252 & & 15,252 & \\
\hline
\end{tabular}

Notes: $* * *$ significant at $1 \%$, and $* *$ significant at $5 \%$. Transactions are expressed in Lao Kip (unit: 1,000 Kip).

Source: Author's calculation using data obtained from VIOT, Household Survey 2016.

\section{Impact of Remittances on Consumption}

Table 9 presents the ATET estimates of households with remittances (WRs) for the entire sampleon a set of various outcomes related to consumption expenditures and its composition. Concerning disaggregate consumption expenditures by major goods, three major components reveal the impact and contribution of remittances increasing when a household receives remittances: expenses for consumer goods such as rice, poultry, and livestock, respectively. We also find that remittances havea positive impact on education, this is opposite with the studies of Démurger, S., \& Wang, X. (2016). However, its impact on healthcare service is positive, but it is insignificant. This is due to lack of nursery services in the village, even though, there is a healthcare center in the village, but there are no nurses available for a year-round. NTFPs is insignificant, because the fact that most NTFPs are sold outside the village. In addition, Crops are also insignificant, since all households in this villagehave their own vegetables plots and they are producing for own consumption. The results of ATETby PSM method reveal that a $1,000 \mathrm{Kip}($ US $\$ 1,2)$ increase in remittances is associated with an average of 398,545 Kip (US\$ 49,81), 312,545 Kip (US\$ 39,06), 150,909 Kip (US\$ 18,86), and 132,363 Kip (US\$ 16,54) increase in livestock, rice, education, and poultry consumption expenditure, respectively. These findings indicate that households with remittances in rural Lao PDRspend much on consumer goods and services (e.g. rice, livestock, and poultry), whereas expenses for education is also significantly increased, this means that remittances have a positive significant impact on rural household education, because the fact that there is high school provided and built bylocal government, and most households are aware of significance of education for their children.

\footnotetext{
${ }^{3}$ Exchange rate between US dollar to Lao Kip at the time of study was 8000 Kip.
} 
This finding is opposite with the studies of Démurger, S., \& Wang, X (2016), Nguyen, D.L., et al (2017). But this finding shows a similar result with other studies (Adams, R.H., \& Cuecuecha, A. 2013).

Table 9: ATET Estimation: Impact Of Remittances On Consumptions

\begin{tabular}{|c|c|c|c|c|c|c|c|c|c|c|}
\hline \multirow{2}{*}{$\begin{array}{c}\text { Remittance } \\
\text { (1 vs } 0)\end{array}$} & \multicolumn{2}{|c|}{ PSM } & \multicolumn{2}{|c|}{ NN-MATCH } & \multicolumn{2}{|c|}{ IPW } & \multicolumn{2}{|c|}{ IPWRA } & \multicolumn{2}{|c|}{ RA } \\
\hline & ATET & S.E. & ATET & S.E. & ATET & S.E. & ATET & S.E. & ATET & S.E. \\
\hline (1) Rice & $312.545^{* * *}$ & 107.22 & 219.636 & 198.83 & $289.436 * *$ & 157.99 & $290.202^{*}$ & 155.90 & $285.919 *$ & 158.59 \\
\hline $\begin{array}{l}\text { (3) Lives } \\
\text { tock }\end{array}$ & $398.545^{* *}$ & 189.91 & 310.727 & 192.88 & $346.154^{* *}$ & 188.07 & $345.605^{*}$ & 188.66 & $344.032 *$ & 189.02 \\
\hline $\begin{array}{l}\text { (6) Educa- } \\
\text { tion }\end{array}$ & $150.909 * *$ & 57.192 & $183.636 * *$ & 85.946 & 100.22 & 66.569 & 100.572 & 65.673 & 103.183 & 65.230 \\
\hline $\begin{array}{l}\text { (7) Health- } \\
\text { care }\end{array}$ & 889.090 & 716.68 & 887.272 & 725.43 & 923.632 & 725.10 & 923.239 & $\begin{array}{l}725 . \\
69\end{array}$ & 929.455 & 726.18 \\
\hline
\end{tabular}

Notes: $* * *, * *$, and $*$ significant at $1 \%, 5 \%$, and $10 \%$, respectively. Transactions shown here are expressed in Lao Kip (unit: 1,000 Kip)

Source: Author's calculation using data obtained from VIOT, Household Survey 2016.

\section{Impact of Remittances on Investment (stock)}

Table 10 presents the ATET estimates of the households with remittances (WRs) for the entire sample on a set of various outcomes related to the investment expenditure and its composition. Indeed, ATET estimates suggest that remittances have a significant impact on supporting investmentin major tradable products and some productive assets as rice, livestock, food products and farm inputs (e.g. fertilizer, tools, equipment, and motor vehicles. These findings reveal that a $1,000 \mathrm{Kip}$ (US\$1,2) increase in remittances is associated with an average of $11,776,000$ Kip (US\$1,472), and1,667,810 Kip (US\$ 208,47) increase in accumulated stock of rice product and livestock for future use and investment, respectively. This suggests that remittances had a more significant contributionto increased stock of products or savings rather than consumption in the corresponding village. Thisfinding is usually different from previous studies (Démurger, S., \& Wang, X., 2016; Piras et al. (2018). Démurger, S., \& Wang, X. (2016) find that remittances supplement income in rural China and lead to increased consumption rather than investment. This is due to a difference in remittance uses. Moreover, during times of market access constraint, and food insecurity in this village, remittances tend to be used for non-consumption purposes (e.g. savings and investment). these domestic money transfers can offer an important economic buffer, provide more direct or indirect benefit by acting as a safety net, giving more cashesinto local commerce, whereas the extra demand for products and services helps develop local marketsand supports business.

Table 10: ATET Estimation: Impact of Remittances on Investment (Stock)

\begin{tabular}{|c|c|c|c|c|c|c|c|c|c|c|}
\hline \multirow{2}{*}{$\begin{array}{l}\text { Remittance } \\
\text { (1vs 0) }\end{array}$} & \multicolumn{2}{|c|}{ PSM } & \multirow{2}{*}{$\begin{array}{c}\text { NN-MATCH } \\
\text { ATET }\end{array}$} & \multirow[b]{2}{*}{ S.E. } & \multicolumn{2}{|c|}{ IPW } & \multicolumn{2}{|l|}{ IPWRA } & \multicolumn{2}{|c|}{ RA } \\
\hline & ATET & S.E. & & & ATET & S.E. & ATET & S.E. & ATET & S.E. \\
\hline (1) Rice & $11776.45^{* *}$ & 6241.49 & $11771.82^{* *}$ & 6241.96 & $11777.76^{* *}$ & 6241.97 & $11777.61^{* *}$ & 6242.29 & $11777.320^{* *}$ & 6242.27 \\
\hline (2) NTFPs & $5836.68^{*}$ & 3099.59 & 5839.773* & 3102.86 & 5834.486* & 3100.00 & $5834.272^{*}$ & 3100.25 & $5835.125^{*}$ & 3099.63 \\
\hline
\end{tabular}




\begin{tabular}{|c|c|c|c|c|c|c|c|c|c|c|}
\hline \multirow{2}{*}{$\begin{array}{l}\text { Remittance } \\
\text { (1vs 0) }\end{array}$} & \multicolumn{2}{|c|}{ PSM } & \multicolumn{2}{|l|}{ NN-MATCH } & \multicolumn{2}{|c|}{ IPW } & \multicolumn{2}{|l|}{ IPWRA } & \multicolumn{2}{|c|}{ RA } \\
\hline & ATET & S.E. & ATET & S.E. & ATET & S.E. & ATET & S.E. & ATET & S.E. \\
\hline (3) Livestock & $1667.81 * * *$ & 690.752 & $1438.182 * *$ & 730.357 & $1234.310 *$ & 707.168 & $1228.227^{*}$ & 711.095 & $1239.166^{*}$ & 706.951 \\
\hline (4) Poultry & 68.000 & 52.0723 & $139.727 * *$ & 74.0996 & $117.240^{*}$ & 68.4965 & $117.412^{*}$ & 69.1588 & $117.944^{*}$ & 68.849 \\
\hline (5) Crops & $6.454 *$ & 03.4776 & -1.181 & 06.3170 & -0.735 & 4.7348 & -0.708 & 4.6439 & -0.649 & 4.6597 \\
\hline $\begin{array}{l}\text { (6) Farm } \\
\text { inputs }\end{array}$ & 13481.09 & 8557.17 & 13160.00 & 8545.00 & 13415.68 & 8541.58 & 13413.70 & 8543.63 & 13406.81 & 8542.69 \\
\hline $\begin{array}{l}\text { Observation } \\
\text { (N) }\end{array}$ & 124 & & 124 & & 124 & & 124 & & 124 & \\
\hline
\end{tabular}

Notes: $* * *, * *$, and $*$ significant level at $1 \%, 5 \%$, and $10 \%$, respectively. Transactions shown here are expressed in Lao Kip (unit: 1,000 Kip). Farm inputs include fertilizer, tools, equipment, and motor vehicles. Source: Author's calculation using data obtained from VIOT, Household Survey 2016 conducted by authors.

\section{Conclusion}

This paper explores how domestic remittances affect the mutual transactions among households with remittances through their trade of locally-produced products as the intermediate inputs and intermediate demand for production and livelihood in a rural developing country. Using origin-to- destination (OD) data obtaining from our own Household Survey 2015 and 2016 when we made a VIOT for a rural village in northern Lao PDR, we can examine the influence of remittances on mutualtransactions, consumption, and investment by estimate the average treatment effects on the treated (ATET).

Our main findings reveal that remittances have a significant positive impact on mutual transactions among households with remittances (WRs) through their trade of locally-produced products. Among transactions, rice is the main trade transaction in the village, contributing a major role in total transactions among WRs, this is followed by NTFPs, livestock, poultry, and crops transactions, respectively. Remittances can act as a facilitator in mutual transactions. This means thata 1,000 Kip increase in remittances world lead to a 47,838 Kip, 20,860 Kip, and 13,720 Kip increasein rice, NTFPs, and livestock transactions among households with remittances, respectively. In addition, remittances have positive impact on increased accumulation of products (stock) rather thanconsumption in the village. Because several households are subject to income volatility and seasonality in the corresponding village, they prefer to stockpile or save their products for emergencyor future use instead of selling to other households. Remittances may help supplement income and easing the budget constraints for those who are vulnerable. Regarding the transactions of rural households, the key results are threefold. First, Households with remittances (WRs) are found to frequently trade rice, livestock, and poultry with each other. They spend more on intermediate inputsand intermediate demand, accumulated products for investments, and less on consumption, except expenses for healthcare services. Second, within consumption expenditure and its composition, households with remittances are found to favor consumption on food products such as rice, poultry,and healthcare services. This suggests that rural households in Lao PDR tend to pay attention to quality of life improvement and livelihood. Third, WRs are found to increasingly invest in major tradable products that they can produce locally. This study provides a strong evidence of positive impact of remittances on mutual transactions. In addition, the study also finds the similar positive impact of remittance on consumption and investment. Remittances sent by their family members who are migrants offer an important economic buffer, provide more direct or indirect benefit by acting as a safety net, giving more cashes into local commerce, whereas the extra demand for products and services helps develop local markets and supports business. Therefore, with the recognition of the impact that remittances have on transactions among households and the role of domestic money transfers through remittances, it is necessary for local governments and the privatesector to explore ways to maximize this impact by scaling up 
successful policies and models.

This paper contributes an interesting finding to the empirical literature on the effects of remittances on transactions through the inter-household trading of locally-produced products, usinginformation of individual household sales to other households and purchases from other householdswithin the study village and remittances received in previous year by households in the village. First, we complement previous studies by using a propensity score matching (PSM) approach that allow us to estimate the impact of remittances on the inter-household investment-type and consumption- type expenditures. This is very important because as noted in Démurger, S. \& Wang, X. (2016) estimates of consumption and investment effects of remittances based on PSM that accounts for theselection of households into receiving remittances and estimate average treatment effects on the treated. Second, unlike large-scale databases used in previous studies, our household survey databaseis unique because the data are extremely detailed, capturing all household transactions, expendituresand their compositions. Our main dataset and analysis cover almost 15,252 household pairs in total. This dataset is originally obtained from our VIOT, which is in a matrix form of $123 \times 124$ size. We focus on the differentiated impact of remittances on various transactions of locally-producedproducts, especially inter-household trading of intermediate inputs and intermediate demand, whichallows us to explore the potential impact of remittances on transactions and extend the debate concerning whether remittances do serve any investment purpose in rural Lao PDR.

Second, we identify whether remittances raise an endogeneity issue: there might be confounding factors that influence both the likelihood of receiving remittances and the household'sconsumption-type and investment-type expenditure behavior. Thus, in our regression estimates we allow the impact of remittances on transactions to be different for each household in the village, weapply propensity score matching (PSM) approach to investigate the impact of remittances on transactions through trading of locally-produced products among households within the village. ThisPSM method offers the advantage of controlling for self-selection based on observable characteristicswithout imposing too strong distributional assumptions (Jimenez-Seto \& Brown, 2012; Démurger, S. \& Wang, X. 2016).

Third, our findings advocate a new evidence to the empirical literature on the impact of remittances on the inter-household transactions. We find that remittances have statistically significant transactions-increasing effects that appear to operate mainly through increase in rice andnon-timber forest products (NTFPs) trading of remittances-receiving households. Indeed, PSM approach suggests that while estimating average treatment effects on the treated (ATT), we find thata 1,000 Kip (US\$ 1,2) increase in remittances would lead to an average of 47,838 Kip (US\$ 5,97) increase in rice transactions among households with remittances, while a 1,000 Kip (US\$1,2) increase in remittances is associated with an average of 11,776 thousand Kip or (US\$1472,05) increase in accumulated stock of rice product for investment, and an average of $312,545 \mathrm{Kip}$ or (US\$39,06) increase in rice consumption. This suggests that remittances had a more significant contribution to increased accumulation (stock) of intermediate inputs and final products rather than consumption in the corresponding village. This may be due to many poor households in the village tend to save money and keep their products for emergency use or during a time of rice or products shortage. This finding is different from other previous studies (Démurger, S. \& Wang, X. 2016), which reveals that remittances lead to increased consumption rather than increased investment in rural China.

\section{Acknowledgements}

We are grateful to all collaborators and advisors in Development Policy Division of Graduate Schoolfor International Development and Cooperation (IDEC), Hiroshima University for their useful and constructive comments to write this article.

\section{Funding}


This research was financially supported by a grant-in-aid from the Zengin Foundation for Studies onEconomics and Finance in 2016 and Japan Society for the Promotion of Science (JSPS) KAKENHI[Grant Number JP 16 H05704].

\section{Conflicts of Interests}

The authors declare that they have no conflict of interests.

\section{References}

Acosta, P., Calderón, C., Fajnzylber, P., \& Lopez, H. (2008). What is the Impact of International Remittances on Poverty and Inequality in Latin America? World Development, 36(1). https://doi.org/10.1016/j.worlddev.2007.02.016

Adams, R. H., \& Cuecuecha, A. (2010). Remittances, household expenditure and investment in guatemala. World Development, 38(11). https://doi.org/10.1016/j.worlddev.2010.03.003

Adams, R. H., \& Cuecuecha, A. (2013). The Impact of Remittances on Investment and Poverty in Ghana. World Development, 50. https://doi.org/10.1016/j.worlddev.2013.04.009

Aggarwal, R., Demirgüç-Kunt, A., \& Pería, M. S. M. (2011). Do remittances promote financial development? Journal of Development Economics, 96(2). https://doi.org/10.1016/j. jdeveco.2010.10.005

Ambrosius, C., \& Cuecuecha, A. (2016). Remittances and the Use of Formal and Informal Financial Services. World Development, 77. https://doi.org/10.1016/j.worlddev.2015.08.010

Amuedo-Dorantes, C., \& Pozo, S. (2011). New evidence on the role of remittances on healthcare expenditures by Mexican households. Review of Economics of the Household, 9(1). https://doi.org/10.1007/s11150-009-9080-7

Bertoli, S., \& Marchetta, F. (2014). Migration, Remittances and Poverty in Ecuador. Journal of Development Studies, 50(8). https://doi.org/10.1080/00220388.2014.919382

Bui, T. T. N., Le, T. T. N., \& Daly, K. J. (2015). Microlevel impacts of remittances on household behavior: Viet Nam case study. Emerging Markets Review, 25. https://doi. org/10.1016/j.ememar.2015.10.001

Caliendo, M., \& Kopeinig, S. (2008). Some practical guidance for the implementation of propensity score matching. Journal of Economic Surveys, 22(1). https://doi.org/10.1111/ j.1467-6419.2007.00527.x

Coulibaly, D. (2015). Remittances and financial development in Sub-Saharan African countries: A system approach. Economic Modelling, 45, 249-258.

Clément, M. (2011). Remittances and household expenditure patterns in Tajikistan: A propensity score matching analysis. Asian Development Review, 28(2). https://doi. org/10.2139/ssrn.2001145

Combes, J. L., \& Ebeke, C. (2011). Remittances and Household Consumption Instability in Developing Countries. World Development, 39(7). https://doi.org/10.1016/j.worlddev.2010.10.006 
Démurger, S., \& Wang, X. (2016). Remittances and expenditure patterns of the left behinds in rural China. China Economic Review, 37. https://doi.org/10.1016/j.chieco.2015.12.002

Heckman, J. J., Ichimura, H., Smith, J. A., \& Todd, P. E. (1998). Characterizing selection bias using experimental data.

Jimenez-Soto, E. V., \& Brown, R. P. C. (2012). Assessing the Poverty Impacts of Migrants' Remittances Using Propensity Score Matching: The Case of Tonga. Economic Record, 88(282). https://doi.org/10.1111/j.1475-4932.2012.00824.x

Lee, W. S. (2013). Propensity score matching and variations on the balancing test. Empirical Economics, 44(1). https://doi.org/10.1007/s00181-011-0481-0

López-Feldman, A., \& Chávez, E. (2017). Remittances and Natural Resource Extraction: Evidence from Mexico. Ecological Economics, 132. https://doi.org/10.1016/j.ecolecon.2016.10.010

Meyer, D., \& Shera, A. (2017). The impact of remittances on economic growth: An econometric model. EconomiA, 18(2). https://doi.org/10.1016/j.econ.2016.06.001

Nguyen, D. L., Grote, U., \& Nguyen, T. T. (2017). Migration and rural household expenditures: A case study from Vietnam. Economic Analysis and Policy, 56. https://doi.org/10.1016/j. eap.2017.09.001

Piras, S., Vittuari, M., Möllers, J., \& Herzfeld, T. (2018). Remittance inflow and smallholder farming practices. The case of Moldova. Land Use Policy, 70. https://doi.org/10.1016/j. landusepol.2017.10.050

Rosenbaum, P. R., \& Rubin, D. B. (1983). The central role of the propensity score in observational studies for causal effects. Biometrika, 70(1). https://doi.org/10.1093/biomet/70.1.41

Taylor, J. E., \& Mora, J. (2006). Does Migration Reshape Expenditures in Rural Households: Evidence from Mexico. World Bank, 95616.

Vacaflores, D. E. (2018). Are remittances helping lower poverty and inequality levels in Latin America? Quarterly Review of Economics and Finance, 68. https://doi.org/10.1016/j. qref.2017.09.001 